\title{
Pola Pemberatan Pidana dalam Hukum Pidana Khusus
}

\author{
Chairul Huda \\ Fakultas Hukum Universitas Muhammadiyah Jakarta \\ Jl. KH. Ahmad Dahlan No. 1 Cirendeu Ciputat Jakarta Selatan \\ huda.fabian@yahoo.com
}

\begin{abstract}
What has been a fundamental issue of this study what base for the lawgivers in determining "type and number" of crime showing a disapprobation. Is there any certain pattern used by the lawgivers in determining the case in Special Criminal Code, primarily to do its weighting when compared with the general pattern used in the Criminal Code. This research was conducted by using a normative juridical method, mainly by analyzing the symptoms suggested by the legislators in the enactment of criminal threats. The results of this study indicate that in the Special Criminal Law, becoming the "symbol" of Criminal Law as the identity of Indonesia, there is no specific pattern in conducting the weighting of criminal.
\end{abstract}

Key words: Criminal weighting, the special criminal law, criminal.

\begin{abstract}
Abstrak
Persoalan mendasar berkenaan dengan penelitian ini adalah apakah yang menjadi dasar bagi pembentuk undang-undang untuk menetapkan "jenis dan jumah" pidana yang menunjukkan sifat ketercelaan tersebut. Apakah terdapat pola tertentu yang digunakan pembentuk undang-undang dalam menentukan hal tersebut dalam Hukum Pidana Khusus, terutama untuk melakukan pemberatannya apabila dibandingkan dengan pola umum yang digunakan pembentuk KUHP. Penelitian ini dilakukan dengan menggunakan metode yuridis normatif, terutama dengan melakukan analisis terhadap gejala yang diisyaratkan pembentuk undang-undang dalam ancaman pidana yang ditetapkannya. Hasil penelitian ini menunjukkan bahwa dalam Hukum Pidana Khusus, yang menjadi "simbol" Hukum Pidana berjatidiri bangsa Indonesia, justru tidak ditemukan pola tertentu dalam melakukan pemberatan pidana.
\end{abstract}

Kata kunci : Pemberatan pidana, hukum pidana khusus, ancaman pidana. 


\section{Pendahuluan}

Para ahli hukum tentunya akan bergembira sekali, ketika dapat menemukan suatu kriteria umum tentang apakah yang menjadi dasar menetapkan suatu perbuatan sebagai tindak pidana (krinimalisasi). Tanpa dapat ditentukannya hal itu, umumnya negara-negara akan berada pada keadaan overcriminalize dan overpunish, seperti yang disinyalir oleh Dauglas Husak sebagai "too much punishment, too many crimes". ${ }^{1}$ Suatu keadaan yang menurutnya telah melingkupi termasuk negara demokrasi besar seperti Amerika Serikat. Ternyata pertumbuhan kriminalisasi dewasa ini telah dipandang berbanding lurus dengan kecenderungan umumnya negara untuk "menumpuk" kekuasaan, yang dalam ideologi sekarang justru dipandang negatif.

Keadaan ini menyebabkan diperlukan suatu standar atau ukuran tertentu untuk menentukan bahwa jumlah kejahatan dan berat ringan sanksinya dipandang terlalu sedikit, cukup, atau sudah tepat. ${ }^{2}$ Suatu ukuran kuantitatif yang tidak terlalu biasa digunakan sebagai pendekatan didalam hukum. Pada satu sisi hal ini diperlukan untuk menghindari tudingan bahwa hukum pidana sekedar merupakan manipulasi nilai-nilai (tertentu) yang dilakukan dengan sengaja oleh pemegang kekuasaan, seperti dikatakan Freiberg. ${ }^{3}$ Kriminalisasi in abstracto, dapat menjadi suatu kebijakan legislatif yang tidak berpola, terutama ketika pembentuk undang-undang lalai merujuk dasar pencelaan suatu perbuatan atau gagal menetapkan hal itu.

Secara umum, suatu rumusan tindak pidana, setidaknya memuat rumusan tentang: (1) subyek hukum yang menjadi sasaran norma tersebut (addressaat norm); (2) perbuatan yang dilarang (strafbaar), baik dalam bentuk melakukan sesuatu (commission), tidak melakukan sesuatu (omission) dan menimbulkan akibat (kejadian yang ditimbulkan oleh kelakuan); dan (3) ancaman pidana (strafmaat), sebagai sarana memaksakan keberlakuan atau dapat ditaatinya ketentuan tersebut. Sejauh ini, belum terdapat pedoman yang memberikan batasan yang cukup jelas tentang bagaimana merumuskan dan mengkaitkan ketiga aspek dari tindak pidana di atas, kecuali pembahasan-pembahasan teoretis yang disana-sini masih menjadi perdebatan antara ahli yang satu dengan yang lain. Undang-Undang No. 12 Tahun

\footnotetext{
${ }^{1}$ Dauglas Husak, Overcriminalization; The Limits of the Criminal Law, Oxford University Press, New York, 2008, hlm. 4

${ }^{2}$ Ibid.

${ }^{3}$ Dirk Merckx, Sanctioning Economic Crime, VUB University Press, Brussels, 2006, hlm. 190.
} 
2011 tentang Pembentukan Peraturan Perundang-undangan (sebagai penyempurnaan UU No. 10 Tahun 2004), memang telah memberikan pedoman dalam perancangan suatu peraturan perundang-undangan, tetapi sekalipun sedikit banyak disinggung, belum memberikan acuan yang konprehensif tentang bagaimana merumuskan suatu "tindak pidana". Baik ketika hal itu menjadi bagian "Ketentuan Pidana" dalam undang-undang administratif (ordnungswidrigkeinten-recht), maupun ketika merumuskannya dalam undang-undang pidana.

Salah satu hal yang cukup banyak menyita perhatian para ahli maupun masyarakat pada umumnya, berkenaan dengan perumusan "acaman pidana" atau "strafmaat". Dengan meminjam istilah David Givens, bahwa kejahatan baik sebelum maupun setelah dilakukan selalu memberikan "crime signals", ${ }^{4}$ maka hal sama dinyatakan negara dengan "pidana". "Crime signals" yang dinyatakan pembentuk undang-undang sebelum kejahatan dengan "ancaman pidana", sedangkan setelah kejahatan dilakukan lewat "pidana yang dijatuhkan" oleh hakim. Hal ini merupakan representasi "ketercelaan" terhadap suatu tindak pidana dan pembuatnya.

Perhatian mengenai hal ini menjadi semakin penting, mengingat hasil kegiatan pengaturan (regeling) setelah Indonesia merdeka, khususnya yang dirumuskan sebagai Hukum Pidana Khusus, merupakan gambaran hukum pidana asli Indonesia. Kenyataan bahwa dalam Hukum Pidana Khusus masih kerap digunakan sanksi pidana yang berat, seperti pidana penjara seumur hidup dan pidana mati, menyebabkan sorotan yang mempersoalkan landasan filosofis yang dianut pembangunan dan pembaharuan hukum pidana Indonesia, tidak dapat dihindarkan. Pikiran post modern tentang pidana, sepertinya tidak terlalu membekas, yang menempatkan Indonesia kembali dikelompokkan kepada classical school, setidaknya neo-classical school. Bertolak belakang dengan kecenderungan negara-negara yang mengadakan moratorium penggunaan capital punishment, sebelum dapat diintroduksi "guided discretion" tentang hal ini, ${ }^{5}$ Indonesia justru mengkapitalisasi penggunaan ultimate sanction tersebut.

Perhatian mengenai hal ini menajam sehubungan dengan "pola" pemberatan pidana, yaitu apabila dibandingkan dengan tindak pidana umum yang terdapat

\footnotetext{
${ }^{4}$ David Givens, Crime Signals; How to Spot a Criminal Before You Become a Victim, ST. Martin's Griffins, New York, 2009, hlm. 3.

${ }^{5}$ Robert M. Bohm, Ultimate Sanction; Understanding The Death Penalty Through Its Many Voices And Many Side, Kaplan Publishing, New York, 2010, hlm. vi.
} 
dalam KUHP dengan Undang-Undang Pidana Khusus, yaitu pemberatan pidana yang dilakukan terhadap tindak pidana yang mempunyai unsur khusus, sehingga eksepsi dari sistem pemidanaan seolah mendapat pembenaran. Tanpa adanya pola yang memadai akan menimbulkan persoalan disparitas pidana yang dapat mengusik rasa keadilan. Belum lagi konsekuensinya pemberatan pidana tanpa suatu pola tertentu, dapat berakibat pada beralihnya suatu suatu tindak pidana dari nonarrestable crime menjadi arrestable crime. Dengan kata lain, seperti disinyalir Tim Newburn, pembedaan tentang hal itu tidak lagi eksis, ${ }^{6}$ akibat kecenderungan memudarnya definisi serious crime, dalam level perundang-undangan. Tidak mengherankan apabila abesensi penggunaan pola dalam hal ini dapat berdampak pada munculnya (potensi) praktik diskriminatif dalam penegakan hukum.

Berdasarkan uraian di atas, penulis setelah melakukan penelusuran dan pengkajian mengenai pola pengancaman pidana, khususnya pola pemberatan pidana dalam Undang-Undang Pidana Khusus, memandang perlu untuk menyajikannya dalam artikel ini. Setidaknya dapat dijadikan perhatian bagi para ahli dan perumusan undang-undang pada kesempatan mendatang.

\section{Rumusan Masalah}

Penelitian ini terutama menyoroti hal-hal yang sifatnya "memola" dari pengancaman pidana pada umumnya dan pengancaman pidana dalam undangundang pidna khusus di luar KUHP. Oleh karena itu, pembandingan terutama dilakukan antara ancaman pidana dalam ketentuan-ketentuan pidana di luar KUHP dengan "padanannya" di dalam KUHP, yaitu melihat bagaimana hal itu sebagai " $a$ generic crime". Pertanyaan mendasar di sini adalah: (1) apakah dapat ditemukan suatu pola pengancaman pidana dalam undang-undang? dan (2) bagaimanakah pola pemberatan pidana dalam undang-undang di luar KUHP, khususnya yang termasuk undang-undang pidana khusus?

\section{Tujuan Penelitian}

Tujuan utama penelitian ini adalah menemukan pola pemberatan ancaman pidana di dalam KUHP, yang kemudian menjadi standar mengkaji perumusan

${ }^{6}$ Tim Newburn, Criminology, Willan Publishing, Portland, 2007, hlm. 608. 
ancaman pidana dalam undang-undang pidana khusus. Oleh karena itu, sebelum lebih jauh membicarakan tentang "pola" pemberatan pidana dalam Hukum Pidana Khusus, pertama-tama harus dikemukakan terlebih dahulu hal ikhwal yang berhubungan dengan pengancaman pidana, pola pemberatan pidana dan hukum pidana khusus.

\section{Metode Penelitian}

Tujuan utama penelitian ini adalah menemukan pola pemberatan ancaman pidana di dalam KUHP, yang kemudian menjadi standar mengkaji perumusan ancaman pidana dalam undang-undang pidana khusus. Dengan demikian, penelitian ditujukan untuk menemukan hal yang menjadi dasar bagi pembentuk undang-undang untuk menetapkan "jenis dan jumlah" pidana, dalam suatu tindak pidana. Penelitian karenanya juga bertujuan untuk mendapatkan gambaran tentang pola tertentu yang digunakan pembentuk undang-undang dalam menentukan hal tersebut dalam Hukum Pidana Khusus, terutama untuk melakukan pemberatannya apabila dibandingkan dengan pola umum yang digunakan pembentuk KUHP.

Penelitian dilakukan dengan pendekatan pure normative, berkenaan dengan pola yang digunakan (pembentuk) undang-undang dalam hal ini, sehingga merupakan manuskrip tentang penemuan pola pengancaman pidana pada umumnya, dan tentunya pemberatannya. Perhatian terhadap "perilaku" pembentuk undang-undang melalui produk kreasinya memang selalu menarik untuk dilakukan, terlebih dalam hukum pidana yang masih mengidolakan lex scipta.

Pemberatan pidana yang diteliti meliputi aspek kualitas maupun kuantitas pidana. Dimaksud dengan kualitas di sini apabila pemberatan terjadi karena perubahan dari satu jenis pidana yang lebih ringan kepada jenis pidana lain yang lebih berat, dengan memperhatikan ketentuan Pasal 69 KUHP. Sedangkan pemberatan dari aspek kuantitas di sini adalah apabila jumlah pidana bertambah dari jumlah pidana yang diancamkan sebelumnya. 


\section{Hasil Penelitian dan Pembahasan}

\section{Pola Pemberatan Pidana dalam KUHP}

Pola pemberatan pidana merupakan bagian dari pola pemidanaan. Menurut Barda N. Arief, pola pemidanaan merupakan pedoman pembuatan atau penyusunan pidana bagi pembentuk undang-undang, yang dibedakan dengan pedoman pemidanaan yang merupakan pedoman bagi hakim dalam menjatuhkan pidana. ${ }^{7}$ Pola pemidanaan (termasuk pola pemberatan pidana) pada dasarnya merupakan suatu gejala yang tersirat dari ancaman pidana yang terdapat dalam rumusan tindak pidana dalam perundang-undangan, ${ }^{8}$ yang dengannya dapat diketahui kehendak pembentuk undang-undang berkenaan dengan jumlah dan jenis pidana yang seyogianya dijatuhkan terhadap seorang pembuat tindak pidana. Dengan demikian, pola pemberatan pidana adalah pedoman (yang telah digunakan) pembentuk undang-undang dalam menentukan pemberatan pidana, antara rumusan ancaman pidana yang terdapat dalam Hukum Pidana Khusus apabila dibandingkan dengan rumusan delik umum yang "mirip" dalam KUHP (generic crime). Hal ini mengharuskan terlebih dahulu harus dikemukakan Pola Pemberatan Ancaman Pidana dalam KUHP.

Pola pemberatan ancaman pidana dalam KUHP dapat dibedakan dalam dua kategori. Pertama, dalam kategori umum pemberatan pidana yang diatur dalam Aturan Umum Buku I KUHP. Dalam hal ini, KUHP menggunakan "pola” yang seragam, misalnya pemberatan karena adanya perbarengan, baik karena concursus idealis, concursus realis maupun voortgezette handeling (sekalipun terdapat teknik pemberatan yang berbeda satu sama lain). Dalam hal ini ancaman pidana yang ditentukan (yang dapat atau yang jumlahnya dapat dijatuhkan) menjadi sepertiga lebih berat dari ancaman pidana yang terdapat dalam rumusan delik tersebut yang memuat ancaman pidana yang terberat. Pola pemberatan pidana dengan menambahkan pidana penjara sepertiga lebih berat karena adanya perbarengan

\footnotetext{
${ }^{7}$ Barda N. Arief, Bunga Rampai Kebijakan Hukum Pidana, Citra Adtya Bhakti, Bandung, 1996, hlm. 167-8

${ }^{8}$ Bandingkan dengan Barda N. Arief, Loc. Cit., yang menyatakan bahwa "pola pemidanaan" yang bersifat umum dan ideal harus ada lebiih dahulu sebelum perundang-undangan pidana dibuat, bahkan sebelum KUHP dibuat, sehingga pada dasarnya pola ini sebenarnya harus diperoleh "diluar dari ketentuan undang-undang". Oleh karena itu, penulis pada dasarnya tidak menggunakan pembedaan demikian (perbedaan pola dan pedoman pemidanaan) karena hampir tidak mungkin untuk mendapatkannya. Pola pemidanaan disini adalah "gabungan" dari pola dan pedoman pemidanaan sebagaimana yang dimaksud oleh Barda.
} 
tersebut dalam banyak hal juga diikuti oleh RUU KUHP. ${ }^{9}$ Penggunaan pola ini dipertahankan sebagai cerminan dari diterimanya paham utilitarian, sehingga kumulasi murni digunakan secara terbatas. Berbeda halnya dengan Amerika Serikat yang menggunakan kumulasi murni (zuivere cumulatie), ${ }^{10}$ untuk setiap bentuk perbarengan, sehingga cenderung berbasis retributif dalam penentuan pidananya.

Kedua, dalam kategori khusus pemberatan pidana yang diatur dalam aturan tentang Tindak Pidana (Kejahatan dan Pelanggaran) dalam rumusan delik yang terdapat dalam Buku II dan Buku III KUHP. Pola pemberatan khusus ini, juga dapat dibedakan ke dalam dua kelompok. Kelompok pertama merupakan pemberatan dalam kategori khusus yang seragam, yaitu pemberatan pola seragam seperti pemberatan dalam kategori umum, yaitu diperberat sepertiga. Dalam hal ini ancaman pidana diberatkan karena adanya pengulangan (recidive) delik. Ancaman pidana juga diberatkan karena adanya kualitas khusus pelaku (subjek delik), misalnya karena sebagai pegawai negeri. Selain itu, ancaman pidana juga diberatkan karena kualifikasi khusus dari objek delik, seperti penganiayaan yang dilakukan terhadap ibu, bapak, istri atau anak pelaku, yang pidananya ditambah sepertiga dari maksimum khususnya.

Kelompok kedua merupakan pemberatan dalam kategori khusus yang tidak seragam, yaitu pemberatan pidana dilakukan baik dengan peningkatan kualitas maupun kuantitas ancaman pidananya. Pemberatan terjadi karena perubahan jenis pidana, misalnya perubahan jenis pidana penjara menjadi pidana mati dalam pembunuhan berencana. Disini pola pemberatan ancaman pidana dalam KUHP adalah menggunakan skema, bahwa dalam hal maksimum khusus dalam suatu tindak pidana sama dengan maksimum umum untuk pidana penjara, maka pidana yang diancamkan beralih menjadi jenis pidana yang lebih berat (pidana mati).

Pemberatan terhadap jumlah pidana juga dapat dilakukan dengan menambahkan jumlah maksimum khusus. Dalam hal ini pemberatan dilakukan karena adanya unsur khusus (yang dapat berupa kelakuan atau akibat) dari strafbaar suatu tindak pidana. Contoh yang paling menarik mengenai hal ini adalah dalam penganiayaan, yang jika dirinci pemberatannya akan tergambar sebagai berikut: 1 . penganiayaan, diancam dengan pidana penjara 2 (dua) tahun; 2. penganiayaan yang

${ }^{9}$ Barda, Op.Cit., hlm. 175.

${ }^{10}$ Andi Zaenal Abidin dan Andi Hamzah, Bentuk-bentuk Khusus Perwujudan Delik dan Hukum Penitensier, Raja Grafindo Persada, Jakarta, 2006, hlm. 238. 
mengakibatkan luka berat, diancam dengan pidana penjara 5 (lima) tahun; 3. penganiayaan yang mengakibatkan kematian, diancam pidana penjara 7 (tujuh) tahun; 4. penganiayaan dengan rencana, diancam pidana penjara 4 (empat) tahun; 5. penganiayaan dengan rencana yang mengakibatkan luka berat, diancam pidana penjara 7 (tujuh) tahun; 6. penganiayaan dengan rencana yang mengakibatkan kematian, diancam pidana penjara 9 (sembilan) tahun; 7. melukai berat, diancam pidana penjara 8 (delapan) tahun; 8 . melukai berat yang mengakibatkan kematian, diancam dengan pidana penjara 10 (sepuluh) tahun; 9. penganiayaan berat yang direncanakan lebih dulu, diancam pidana penjara 12 (dua belas) tahun; 10. penganiayaan berat yang mengakibatkan kematian, diancam pidana penjara 15 (lima belas) tahun.

Dari gambaran di atas, terlihat suatu pola bahwa pemberatan karena adanya unsur tambahan, yang dapat berupa kelakuan (perencanaan) atau kejadian yang timbul dari kelakuan atau akibat (luka berat atau kematian) tertentu, dengan menambahkan ancaman pidana penjara menjadi 2 (dua) sampai dengan 3 (tiga) tahun lebih berat apabila dibandingkan dengan rumusan delik yang memiliki sifat lebih umum. Dalam hal ini pemberatan tidak mengikuti pola umum yang terbilang (prosentase) seperti pemberatan dalam kategori umum, tetapi hanya penambahan jumlah pidana tertentu yang berkisar antara 2 (dua) sampai dengan 3 (tiga) tahun.

Pemberatan juga dapat dilakukan karena kekhususan waktu, cara, tempat, alat atau dalam keadaan tertentu, seperti dalam tindak pencurian dengan pemberatan sebagaimana dimaksud dalam Pasal 363 KUHP. Dalam hal ini pemberatan juga dilakukan dengan menambahkan jumlah pidana (dua tahun) lebih berat dalam maksimum khususnya dari ancaman pidana dalam tindak pidana pencurian, sebagaimana dimaksud dalam Pasal 362 KUHP.

\section{Pola Pemberatan Ancaman Pidana dalam Undang-Undang Pidana Khusus}

\section{Pemberatan Umum}

Umumnya dalam UU Pidana Khusus, delik percobaan, pembantuan dan permufakatan jahat suatu tindak pidana diperberat ancaman pidananya, apabila dibandingkan dengan umumnya delik serupa yang diancamkan dalam KUHP. Perbuatan yang masih dalam tingkat percobaan atau pembantuan dalam KUHP 
umumnya diancamkan pidana lebih rendah yaitu dikurangi sepertiga (kecuali dalam tindak pidana makar), apabila perbuatan tersebut dilakukan dengan sempurna (vooltoid), yang dalam tindak pidana korupsi dan tindak pidana terorisme hal ini "diperberat" dengan mengancamkan pidana yang sama seperti jika kejahatan selesai atau diwujudkan oleh pembuat (dader).

Dalam permufakatan jahat untuk melakukan tindak pidana juga diancam pidana lebih berat dalam Hukum Pidana Khusus, yang diancam dengan pidana yang sama ketika perbuatan itu benar-benar diwujudkan. Berbeda halnya dengan umumnya permufakatan jahat dalam KUHP, misalnya, memberi bantuan kepada musuh dalam masa perang diancam dengan pidana penjara 15 (lima belas) tahun, sedangkan pemufakatan jahat terhadap hal itu hanya diancam dengan pidana penjara enam tahun.

Undang-Undang Pidana Khusus juga mengadakan pidana pada perbuatan persiapan (selain permufakatan jahat) yang umumnya dalam KUHP tidak dapat dikenakan pidana. Dalam doktrin tentang percobaan delik misalnya, "perbuatan persiapan" melakukan tindak pidana yang belum dapat dikualifikasi sebagai "permulaan pelaksanaan" yang dapat dipidana, tidak dijadikan tindak pidana. Berbeda halnya dalam tindak pidana penyebaran teror, pidana yang sama diancamkan dengan tindak pidana yang selesai sekalipun masih dalam tahap persiapan, seperti "merencanakan" atau "mengumpul dana" untuk pelaksanaan suatu tindak pidana penyebaran teror. Dalam hal ini, mengingat sama sekali tidak ditemukan padanan deliknya, maka terjadi "lompatan" pemberatan pidana, yaitu dari perbuatan non-kriminal menjadi suatu tindak pidana. Tidak ditemukan dasar etis yang cukup untuk memidana hal itu dengan pidana yang sama ketika perbuatan itu sempurna dilakukan sebagai tindak pidana penyebaran teror. Dalam hal ini ancaman pidana sebenarnya bukan sekedar "sanksi" yang dapat dijatuhkan hakim yan telah ditetapkan dalam undang-undang, tetapi juga merupakan justifikasi moral atas kriminalisasi, terutama tentang pidana apa dan yang bagaimana yang sesuai dan adil. ${ }^{11}$ Pemberantasan terorisme dengan pendekatan penegakan hukum yang bersumberkan keinginan untk menghormati hak asasi manusia, ${ }^{12}$ setelah pendekatan militer dan intelejen dianggap kurang menghormati hak asasi manusia, juga memerlukan justifikasi, termasuk terhadap terorisme yang "mendapat pembenaran"

\footnotetext{
${ }^{11}$ Purwaning M. Yanuar, Pengembalian Aset Hasil Korupsi, Alumni, Bandung, 2007, hlm. 85.

${ }^{12}$ Poltak Partogi Nainggolan, ed., Terorisme dan Tata Dunia Baru, Sekwan DPR RI, Jakarta, 2002, hlm. 115.
} 
dari ajaran Agama sekalipun. ${ }^{13}$ Ketika dalam KUHP penentuan pidana bagi delik percobaan misalnya dilandasi oleh "kehendak jahatnya" ${ }^{14}$ yang telah ternyata, yang dipandang tidak begitu berbahaya apabila dibandingkan dengan delik yang selesai sehingga diancam pidana lebih ringan, maka tidak demikian halnya dengan percobaan terorisme. Demikian pula halnya dengan tindak pidana korupsi dan tindak pidana khusus lainnya. Hal ini dapat diartikan bahwa dalam pandangan pembentuk undang-undang, sekalipun masih dalam tingkat percobaan korupsi dan terorisme dipandang sama berbahayanya dengan delik selesai.

\section{Pemberatan Kualitas Pidana}

Pada dasarnya pemberatan ancaman pidana dengan meningkatkan kualitas pidana dalam UU Pidana Khusus, dapat dibedakan kedalam dua bagian. Pertama, pemberatan apabila dibandingkan dengan kejahatan yang mirip seperti yang terdapat dalam KUHP. Dalam tindak pidana penyebaran teror misalnya, diancam dengan pidana mati setiap orang yang dengan sengaja menggunakan kekerasan atau ancaman kekerasan menimbulkan suasana teror atau rasa takut terhadap orang secara meluas atau menimbulkan korban yang bersifat massal, dengan cara merampas kemerdekaan atau hilangnya nyawa dan harta benda orang lain, atau mengakibatkan kerusakan atau kehancuran terhadap obyek-obyek vital yang strategis atau lingkungan hidup atau fasilitas publik atau fasilitas internasional. Tindak pidana ini pada dasarnya merupakan bentuk khusus dari tindak pidana dalam KUHP yang berupa pembunuhan (diancam pidana 15 tahun), perampasan kemerdekaan (diancam pidana 8 tahun), perusakan fasilitas umum (diancam pidana 4 tahun). Demikian pula halnya dengan kejahatan penerbangan yang dalam KUHP yang diancam dengan pidana yang bervariasi paling ringan 6 (enam) tahun (menghancurkan, membuat tidak dapat dipakai lagi atau merusak sarana penerbangan) dan paling berat diancam dengan pidana penjara 15 (lima belas) tahun (mencelakakan, menghancurkan atau merusak pesawat udara), sementara dalam tindak pidana penyebaran teror mengenai perbuatan yang sama diancam dengan pidana mati.

Pemberatan dengan pola "pukul rata", ini terlihat sangat jomplang dalam UU ITE, jika undang-undang ini dapat dipandang sebagai UU Pidana Khusus. Dalam

\footnotetext{
${ }^{13}$ Walter Reich, ed., Origins of Terrorism, Raja Grafindo Persada, Jakarta, 2003, hlm. 131.

${ }^{14}$ Andi Zaenal Abidin, Op.Cit., hlm. 23.
} 
KUHP, tindak pidana melanggar kesusilaan (diancam pidana 1 tahun 6 bulan), penghinaan (diancam pidana 9 bulan), dan pengancaman (diancam pidana 4 tahun), yang jika dilakukan melalui teknologi informasi, dalam UU ITE diperberat pidananya selama 6 (enam) tahun. Lucunya, dalam rumusan delik UU ITE justru terjadi peringan pidana (yaitu menjadi diancam dengan pidana yang sama (enam tahun)) terhadap perjudian (diancam pidana 10 tahun) dan pemerasan (diancam pidana 9 tahun), sebagaimana ditentukan dalam KUHP.

Pola pukul rata ini cukup banyak ditemukan dalam undang-undang adminitratif yang mempunyai ketentuan pidana. Beberapa pelanggaran kewajiban atau larangan administratif tertentu, yang dilihat sepintas lalu mempunyai tingkat ketercelaan yang berbeda satu dengan yang lain, tetapi ditetapkan strafmaat yang sama. Hal ini boleh jadi wujud ketidakmengertian pembentuk undang-undang tentang "crime signals" yang diemban suatu ancaman pidana.

Dalam hal ini, yang sangat merisaukan adalah penerapan "pola" pemberatan ancaman pidana dalam Hukum Pidana Khusus secara pukul rata ini, menyebabkan beberapa perbuatan yang dalam KUHP diancam dengan pidana penjara, yang dilihat dari jumlahnya tidak merupakan maksimum umum yang dapat diancamkan terhadap pidana penjara, dalam UU Pidana Khusus diperberat menjadi jenis pidana yang lebih berat dari jenis pidana sebelumnya (pidana mati). Hal ini tentunya bertolak belakang dengan pola pemberatan pidana yang ditentukan dalam KUHP.

Kedua, pemberatan pidana dalam UU Pidana Khusus, karena kekhususan deliknya. Dalam tindak pidana korupsi pemberatan pidana dilakukan karena "keadaan tertentu", yang menurut Andi Hamzah, seharusnya "keadaan tertentu ini" dimuat dalam rumusan delik (Pasal 2 ayat (2) dan tidak ditempatkan dalam penjelasannya. ${ }^{15}$ Pada dasarnya menurut penulis "keadaan tertentu" disini berupa kekhususan waktu dilakukannya suatu tindak pidana. Misalnya, dalam tindak pidana korupsi, perbuatan memperkaya diri sendiri, orang lain atau korporasi yang dapat merugikan keuangan negara" yang semula diancam dengan pidana penjara 20 (dua puluh) tahun diperberat menjadi jenis acaman pidana yang lebih berat (pidana mati). Pola ini jarang ditemukan dalam UU Pidana Khusus dan karenanya sama sekali tidak ditemukan pendekatan demikian dalam KUHP. Tambahan lagi menurut Indriyanto Seno Adji ketentuan ini (pola pemberatan pidana secara

${ }^{15}$ Andi Hamzah, Pemberantasan Korupsi Melalui Hukum Pidana Nasional dan Internasional, Pusat Studi Hukum Pidana Universitas Trisakti, Jakarta, 2004, hlm. 103. 
demikian-pen) bertentangan dengan asas legalitas yang melindungi tersangka/ terdakwa apabila terjadi perubahan perundang-undangan (Pasal 1 ayat (2) KUHP), yaitu perubahan itu dalam keadaan yang menguntungkan tersangka/terdakwa. ${ }^{16}$

\section{Pemberatan Kuantitas Pidana}

Pemberatan kuantitas pidana dalam UU Pidana Khusus cukup banyak ditemukan apabila dibandingkan antara delik umumnya dalam KUHP dan delik khususnya. Tindak pidana pornografi yang dalam KUHP diancam pidana penjara paling lama satu tahun empat bulan tetapi diperberat dengan sangat drastis kuantitas pidananya menjadi paling lama 12 (dua belas) tahun, bagi setiap orang yang memproduksi, membuat, memperbanyak, menggandakan, menyebarluaskan, menyiarkan, mengimpor, mengekspor, menawarkan, memperjualbelikan, menyewakan, atau menyediakan pornografi. Pemberatan kuantitas pidana yang cukup drastis tergambar dari tindak pidana kekerasan dalam rumah tangga yang diancam dengan pidana penjara paling lama 6 (enam) tahun 8 (delapan) bulan diperberat dalam UU Pidana Khusus menjadi 10 (sepuluh) tahun penjara.

Tergambar bahwa pembentuk undang-udang tidak menggunakan "pola" tertentu dalam melakukan pemberatan pidana. Pemberatan pidana cenderung dilakukan lebih dari pola pemberatan serupa yang dilakukan KUHP, yaitu ditambah maksimum khususnya 1/3 (sepertiga) lebih berat atau dengan menambah antara 2 (dua) sampai dengan 3 (tiga tahun) dari delik generalisnya.

\section{Pemberatan dengan Perubahan Model Ancaman Pidana}

KUHP hanya mengenal model pengancaman pidana tunggal atau ancaman pidana alternatif. ${ }^{17}$ Artinya, hanya dimungkinkan penjatuhan satu pidana pokok untuk satu delik (single penalty). Beberapa undang-undang di luar KUHP telah menyimpangi pola umum pengancaman pidana dalam KUHP, dengan menggunakan model pengancaman kumulatif (yang ditandai dengan kata penghubung "dan" di antara dua jenis pidana yang diancamkan) atau model kombinasi alternatif-kumulatif yang ditandai dengan kata penghubung "dan/atau" hlm. 53 .

${ }^{16}$ Indriyanto Seno Adji, Korupsi dan Pembalikan Beban Pembuktian, Prof. Oemar Seno Adji \& Rekan, Jakarta, 2006,

${ }^{17}$ Barda, Op.Cit., hlm. 180. 
(diantara dua jenis pidana yang diancamkan). Dengan pengancaman kumulatif maka hakim terikat untuk menjatuhkan pidana kedua jenis pidana tersebut sekaligus (double penalties), yang dapat dipandang sebagai pemberatan pidana. Demikian pula dalam hal ancaman pidana yang menggunakan model alternatif-kumulatif, dijatuhkan oleh hakim menjadi kumulatif. Tanpa pedoman yang menentukan, tidak diperkenankan penjatuhan dua pidana yang diancamkan secara alternatif-kumulatif secara maksimun, akan menyebabkan terjadi pemberatan pidana yang demikian itu.

Persoalannya, pada subyek tindak pidana korporasi, hanya dapat dijatuhkan pidana pokok berupa denda, dan tidak dapat dijatuhkan jenis pidana perampasan kemerdekaan. Mengingat konstruksi ini, akan timbul kesulitan penjatuhan pidana (hanya) terhadap korporasi dalam hal tindak pidana yang dilakukan mengancamkan secara kumulatif pidana-pidana dengan jenis berbeda. Sekalipun salah satu ancaman pidana dalam rumusan tindak pidana adalah denda, tetapi tetap saja dengan model pengancaman kumulatif hakim "harus" menjatuhkan keduanya. Akibatnya, pengancaman pidana terhadap korporasinya menjadi "non applicable". ${ }^{18}$

Pola pemberatan pidana dengan menggunakan model pengancaman pidana kumulatif juga digunakan dalam UU Tindak Pidana Penghapusan Perdagangan Orang. Bandingkan antara perdagangan budak dalam KUHP yang diancam dengan pidana penjara sebagai satu-satunya pidana yang diancamkan (dua belas tahun) diperberat dalam undang-undang khusus menjadi maksimum 15 (lima belas) tahun penjara dan denda sampai dengan Rp.600.000.000,00 (enam ratus juta rupiah). Dalam hal ini juga tidak tergambar apa yang digunakan oleh pembentuk undang-undang sebagai pola pengancaman pidana dengan menggunakan model pengancaman pidana tunggal, pidana kumulatif atau pidana alternatif-kumulatif. Namun demikian, perlu dicatat bahwa perkembangan dalam Hukum Pidana yang memasukkan korporasi sebagai subyek delik justru dapat menjadi faktor yang melatarbelakangi mengapa dalam berbagai undang-undang di luar KUHP, termasuk Undang-Undang Hukum Pidana Khusus, diadakan model pengancaman pidana alternatif-kumulatif, yang dengannya dapat meningkatkan daya tangkis (detterence) sanksi pidana dan sifat jeranya. Mengingat efektivitas pidana denda saja bagi korporasi dipandang rendah karena dapat disiasati dengan menjadikannya sebagai cost of business dan jika denda terlalu membebankan, korporasi dapat mengajukan untuk dipailitkan. ${ }^{19}$

\footnotetext{
${ }^{18}$ Chairul Huda, Op.Cit., hlm. 13.

${ }^{19}$ Rufinus Hotmaulana Hutauruk, Penanggulangan Kejahatan Korporasi, KPG, Jakarta, 2002, hlm. 100.
} 


\section{Pemberatan dengan Pengancaman Minimum Khusus}

Beberapa undang-undang di luar KUHP menggunakan minimum khusus dalam ancaman pidana, sementara sistem ini tidak dikenal dalam KUHP. Penggunaan model demikian juga dapat dipandang sebagai pemberatan pidana. Dengan sistem ini, undang-undang bukan hanya menentukan ancaman pidana maksimum yang dapat dijatuhkan hakim, tetapi juga minimumnya. Hal ini untuk membatasi kemerdekaan hakim yang memang dirasakan terlalu leluasa untuk menjatuhkan pidana antara minimum umum dan maksimum umumnya. Sayangnya tidak terdapat pola umum untuk menentukan delik yang bagaimana yang ditentukan minimum khusus dalam ancaman deliknya. Menurut Barda N. Arief, dalam RUU KUHP, menetapkan minimum khusus dilakukan dengan mempertimbangkan akibat dari delik yang bersangkutan terhadap masyarakat luas (antara lain: menimbulkan bahaya/keresahan umum, bahaya bagi nyawa/kesehatan/lingkungan atau menimbulkan akibat kematian) atau faktor penanggulangan tindak pidana (recidive). ${ }^{20}$

Umumnya undang-undang menempatkan ancaman minimum khusus ini “di depan” ancaman maksimum khususnya. Dengan demikian, ditentukan: “...dipidana dengan pidana penjara paling singkat....dan paling lama...". Demikian pula halnya terhadap denda, ditentukan: “...dipidana dengan denda paling sedikit...dan paling banyak...". Namun demikian, tidak begitu halnya dengan Undang-Undang No. 26 Tahun 2000 tentang Pengadilan Hak Asasi Manusia. Ancaman minimum khususnya disebut lebih kemudian daripada ancaman maksimum khususnya, seperti tersebut dalam Pasal 36, yang menentukan:

"Setiap orang yang melakukan perbuatan sebagaimana dimaksud dalam Pasal 8 huruf $a, b, c, d$, dan e, dipidana dengan pidana mati atau pidana penjara seumur hidup atau pidana penjara paling lama 25 (dua puluh lima) tahun dan paling singkat 10 (sepuluh) tahun".

Memang apabila diperhatikan, penyebutan demikian dipengaruhi oleh model pengancamannya yang alternatif. Ketika pidana diancam secara alternatif, maka ancaman pidana yang paling berat yang disebutkan lebih dahulu. Urut-urutan pidana pokok yang disebutkan dalam Pasal 10 KUHP menentukan berat-ringannya (Pasal 69 KUHP). Dengan demikian, pidana mati disebutkan lebih dulu daripada pidana penjara seumur hidup, dan pidana penjara seumur hidup disebutkan lebih

\footnotetext{
${ }^{20}$ Barda, Op.Cit., hlm. 174.
} 
dahulu dari pada pidana penjara selama waktu tertentu. Pidana penjara selama waktu tertentu yang lebih lama disebutkan lebih dulu daripada pidana penjara selama waktu tertentu yang lebih singkat. Argumen ini juga menjadi gugur, jika diperhatikan ketentuan Pasal 37, 38, 39 dan Pasal 40 Undang-Undang No. 26 Tahun 2000. Di sini ancaman pidana tunggal (hanya pidana penjara selama waktu tertentu), tetapi menggunakan model minimum khusus. Minimum khusus disebutkan kemudian daripada maksimum khususnya.

Menurut penulis, jika ancaman pidana selama waktu tertentu menggunakan rezim minimum khusus, maka tidak pada tempatnya apabila minimum khususnya disebut kemudian. Sekalipun menggunakan minumum khusus, tetap saja harus disebut lebih dulu daripada maksimum khususnya. Penggunaan minimum khusus hanya menentukan rentang pidana yang dapat dijatuhkan hakim, sehingga tidak tunduk pada sistem penyebutan berdasarkan berat-ringannya sebagaimana ditentukan dalam Pasal 69 KUHP di atas. Baru merupakan kekeliruan apabila penyebutan pidana penjara selama waktu tertentu ini lebih dahulu daripada pidana penjara seumur hidup, atau pidana mati. Demikian misalnya dalam Pasal 6 UndangUndang No. 1 Tahun 2003 tentang Terorisme, sekalipun pidana penjara selama waktu tertentu merupakan alternatif dari pidana penjara seumur hidup dan pidana mati, dan dalam hal ini digunakan minimum khusus, maka minimum khusus disebutkan lebih dulu. Dengan demikian dirumuskan: “...dipidana dengan pidana mati atau penjara seumur hidup atau pidana penjara paling singkat 4 (empat) tahun dan paling lama 20 (dua puluh ) tahun".

Berdasarkan hal ini, mestinya Pasal 36 Undang-Undang No. 26 Tahun 2000 Tentang Pengadilan Hak Asasi Manusia menentukan:

Setiap orang yang melakukan perbuatan sebagaimana dimaksud dalam Pasal 8 huruf $a, b, c, d$, dan e, dipidana dengan pidana mati atau pidana penjara seumur hidup atau pidana penjara paling singkat 10 (sepuluh) tahun dan paling lama 25 (dua puluh lima) tahun.

Penyebutan minimum khusus yang lebih kemudian dalam Pasal 37, 38, 39 dan Pasal 40 Undang-Undang No. 26 Tahun 2000, tidak tepat dan seharusnya juga tidak dilakukan secara demikian. 


\section{Penutup}

Penelitian berkenaan dengan pola pemberatan pidana dalam Undang-Undang Pidana Khusus menunjukkan kecenderungan bahwa pembentuk undang-undang sama sekali tidak menggunakan "pola" dalam menentukan ancaman pidana khusus. Dalam banyak segi bahkan sama sekali tidak digunakan pola dalam penalisasi. Perumusan undang-undang tentang tindak pidana (penal policy) dengan cara yang demikian bukan hanya berbahaya, tetapi tidak menjamin terselenggaranya sistem hukum pidana yang adil. Dengan dalih kemerdekaan kekuasaan pembentuk undang-undang yang diberikan prinsip negara hukum, persoalan berpola atau tidak berpola pemberatan pengancaman pidana, boleh jadi menjadi tidak penting. Namun demikian, seperti disinggung George P Fletcher, "the rule of law evens out the risk of injustice over time", ${ }^{21}$ akankah dibiarkan legal policy menebar ketidakadilan? Wallahualam.

\section{Daftar Pustaka}

Abidin, Andi Zaenal dan Andi Hamzah. Bentuk-bentuk Khusus Perwujudan Delik dan Hukum Penitensier, Raja Grafindo Persada, Jakarta, 2006.

Adji, Indriyanto Seno, Korupsi dan Pembalikan Beban Pembuktian, Prof. Oemar Seno Adji \& Rekan, Jakarta, 2006.

Arief, Barda N., Bunga Rampai Kebijakan Hukum Pidana, Citra Adtya Bhakti, Bandung, 1996.

Bohm, Robert M., Ultimate Sanction; Understanding The Death Penalty Through Its Many Voices And Many Side, Kaplan Publishing, New York, 2010.

Huda, Chairul, Kejahatan dalam Bisnis Asuransi, LPHI, Jakarta, 2006.

Fletcher, Gerorge P., Basic Concepts of Criminal Law, Oxford University Press, New York, 1998.

Givens, David, Crime Signals; How to Spot a Criminal Before You Become a Victim, ST. Martin's Griffins, New York, 2009.

Hamzah, Andi, Pemberantasan Korupsi Melalui Hukum Pidana Nasional dan Internasional. Jakarta: Pusat Studi Hukum Pidana Universitas Trisakti, 2004

Husak, Dauglas, Overcriminalization; The Limits of the Criminal Law, Oxford University Press, New York, 2008.

\footnotetext{
${ }^{21}$ Gerorge P. Fletcher, Basic Concepts of Criminal Law, Oxford University Press, New York, 1998, hlm. 206.
} 
Hutauruk, Rufinus Hotmaulana, Penanggulangan Kejahatan Korporasi, KPG, Jakarta 2002.

Merckx, Dirk, Sanctioning Economic Crime, VUB University Press, Brussels, 2006.

Nainggolan, Poltak Partogi, ed., Terorisme dan Tata Dunia Baru, Sekwan DPR RI, Jakarta 2002.

Newburn, Tim, Criminology, Willan Publishing, Portland, 2007.

Reich, Walter, ed., Origins of Terrorism, Raja Grafindo Persada, Jakarta 2003.

Saleh, Roeslan, KUHP dengan Penjelasan, Aksara Baru, Jakarta, 1983.

Yanuar, Purwaning M., Pengembalian Aset Hasil Korupsi, Alumni, Bandung 2007. 